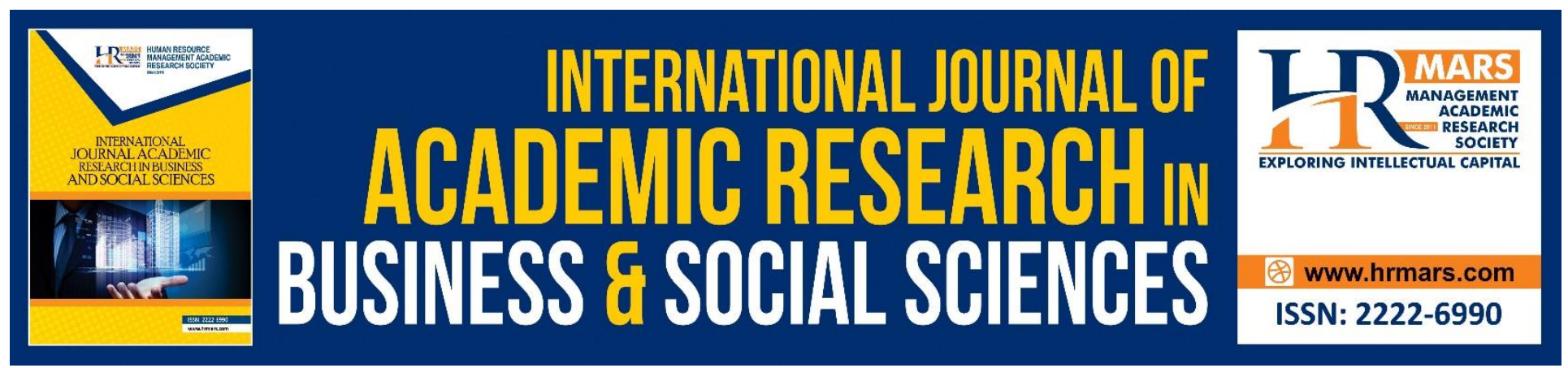

\title{
The Experience of Kindergarten Principals to Provide the Real Similarities and Differences of Managerial Roles in Yogyakarta City
}

Lily Muliana Mustafa Yuli Kurniawati Sugiyo Pranoto

To Link this Article: http://dx.doi.org/10.6007/IJARBSS/v9-i2/5665

DOI: $\quad 10.6007 /$ IJARBSS/v9-i2/5665

Received: 12 Feb 2019, Revised: 27 Feb 2019, Accepted: 12 March 2019

Published Online: 19 March 2019

In-Text Citation: (Mustafa \& Pranoto, 2019)

To Cite this Article: Mustafa, L. M., \& Pranoto, Y. K. S. (2019). The Experience of Kindergarten Principals to Provide the Real Similarities and Differences of Managerial Roles in Yogyakarta City. International Journal of Academic Research in Business and Social Sciences, 9(2), 1078-1086.

Copyright: @ 2019 The Author(s)

Published by Human Resource Management Academic Research Society (www.hrmars.com)

This article is published under the Creative Commons Attribution (CC BY 4.0) license. Anyone may reproduce, distribute, translate and create derivative works of this article (for both commercial and non-commercial purposes), subject to full attribution to the original publication and authors. The full terms of this license may be seen

at: http://creativecommons.org/licences/by/4.0/legalcode

Vol. 9, No. 2, 2019, Pg. 1078 - 1086

http://hrmars.com/index.php/pages/detail/IJARBSS

JOURNAL HOMEPAGE

Full Terms \& Conditions of access and use can be found at http://hrmars.com/index.php/pages/detail/publication-ethics 


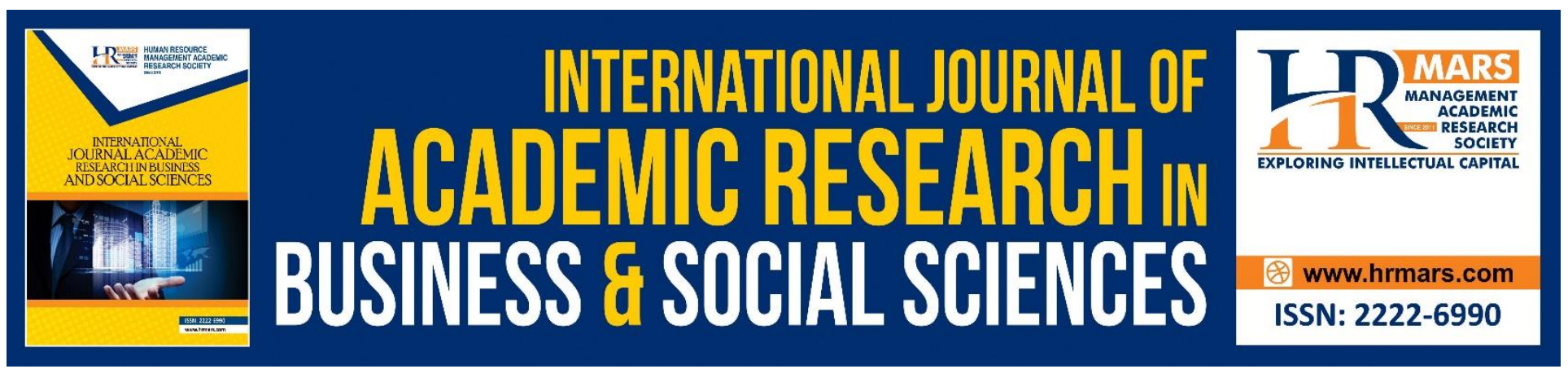

\title{
The Experience of Kindergarten Principals to Provide the Real Similarities and Differences of Managerial Roles in Yogyakarta City
}

\author{
Lily Muliana Mustafa \\ Faculty of Human Development, University Pendidikan Sultan Idris, \\ Tanjong Malim, Perak \\ Yuli Kurniawati Sugiyo Pranoto \\ Universities Negeri Semarang, Kota Semarang, Indonesia
}

\begin{abstract}
Over the past decade, a lot of countries have set ambitious policy goals to increase both the quantity and quality of Early Childhood Education Center. Even though, there is a growing literature on management and professionalism within the Early Childhood Education (ECE), but there is less debate about the real experiences of being a principal in this discussion. Every individual is being encouraged to take part in the managerial roles which is now required by the professionalization agenda although the traditional educators are primarily inspired by a strong desire to work with young children. This article draws on observations and interviews with two principals of private kindergarten in Yogyakarta City, Indonesia. The data collection process involves two principals who had experienced more than 10 years as a teacher and minimal 4 years as a principal. Data were analyzed using content analysis method. The findings show some similarities of both management position for teacher and principal. The differences of both management scope will complement the kindergarten management process. This can be proved by the separated teacher and principal competencies regulated by the Ministry of Education and Culture in Indonesia. In addition, this may avoid the overlapping management work load by two different positions. Indirectly, the educators and principals may respect the management roles of each other. As a conclusion, the experienced principal in the kindergarten environment may determine the similarities and differences of both different positions; teachers and principals. The implications of this study are a quality of principal may produce good performance of teacher and children development. Thus, from this study suggest that experienced principal should ready to motivate new teacher to build up early childhood education career.
\end{abstract}


INTERNATIONAL JOURNAL OF ACADEMIC RESEARCH IN BUSINESS AND SOCIAL SCIENCES

Vol. 9, No. 2, Feb, 2019, E-ISSN: 2222-6990 C 2019 HRMARS

Keywords: Managerial Roles, Experienced Principal, Teacher, Kindergarten Management.

\section{Introduction}

Inclusion of the importance of managerial roles in the ECE centers growing interest to the Ministry of Education, Indonesia. The increasing number of ECE services need to control in order to provide excellent quality for the children and community education benefits. Several basic services are provided to Indonesian children from birth up to age six. There are variety of ECE program implemented such as Posyandu Program, Bina Keluarga Balita parent groups, public kindergarten and Islamic private kindergarten, and nonformal ECE development services. The government also supports pilot programs that offer comprehensive services such as the ECE centers and the Taman Posyandu (World bank, 2015). Table 1 summarizes various type of ECE Institutions and the age allowed for the children to register.

Table 1 : Type of Services in Early Childhood Education (ECE), Indonesia

\begin{tabular}{|l|l|l|}
\hline \multicolumn{1}{|c|}{ ECE Characterization } & \multicolumn{1}{|c|}{ Name of ECE Institutions } & \multicolumn{1}{c|}{ Age of children } \\
\hline Non-formal & Pos PAUD & 3 months until 72 months \\
\hline Non-formal & Taman Penitipan Anak (TPA) & 0 months until 6 years old \\
\hline Non-formal & $\begin{array}{l}\text { PAUD base Taman Pendidikan } \\
\text { Al-Qur'an (TPQ) }\end{array}$ & 0 months until 18 years old \\
\hline Non-formal & $\begin{array}{l}\text { Kelompok Bermain (KB) or } \\
\text { Playgroup }\end{array}$ & 2 years until 6 years old \\
\hline Non-formal & $\begin{array}{l}\text { Taman Kanak-kanak (TK) or } \\
\text { Raudhatul Athfal (RA) }\end{array}$ & 4 years until 6 years old \\
\hline
\end{tabular}

*Pendidikan Anak Usia Dini (ECE)

Sources : Novan ArdyWiyani, 2017

\section{Managerial Roles}

Developing efficient and effectiveness management in the early childhood education (ECE) settings contribute to deliver advantages for children as participants whereby principals as school leaders. Moreover, the support system in preschool include teachers, parents and society may increase the quality of kindergarten management. Each important position should play significant roles to ensure the excellent output services.

A quality of kindergarten management usually controlled by a principal who will lead competent teachers. Thus, effective teachers stimulate young children towards early literacy, mathematics, and social-emotional skills that need to thrive (Bridget, Ann, and Christina, 2017; Mat Ail, Taib, Jaafar, Mohamed Salleh and Omar, 2015; Duangjai and Saowanee, 2014; Yoshikawa, Weiland, Brooks-Gun, Burchinal, Espinosa, Gormley, and Zaslow, 2013).

A lot of research has been written about early childhood teachers' reluctance to embrace managerial and leadership roles (Waniganayake, 2014; Dunlop, 2008; Rodd, 2006; Mujis, Aubrey, Harris \& Briggs, 2004; Ebbeck \& Waniganayake, 2003; Hayden, 1997). Confusion between 
INTERNATIONAL JOURNAL OF ACADEMIC RESEARCH IN BUSINESS AND SOCIAL SCIENCES

Vol. 9, No. 2, Feb, 2019, E-ISSN: 2222-6990 C 2019 HRMARS

kindergarten management issues concerned with day-to-day functions often neglecting organizational development through a shared vision and mission that require efficient and effective management by both position principal and teacher (Waniganayake, 2014). The responsibility of principal to explain and guide every teacher regarding managerial roles will avoid any overlook or repeating tasks. In addition, teachers will ready to replace managerial tasks when principal need to attend any meetings or program required by the MOE.

\section{Experienced Principal}

Formal qualifications in ECE make a difference in supporting management decision making. Asian countries such as Indonesia, provide academic qualification and competencies standard for the benefits of principal and teacher in the kindergarten institution. Table 2 below shows the academic qualification standard required by the Ministry of Education (MOE), Indonesia. The standard qualification shows the concern of Indonesia government to ensure the quality of kindergarten that growth every year.

Table 2: Academic Qualification Standard in ECE centers

\begin{tabular}{|l|l|}
\hline \multicolumn{2}{|c|}{ Academic Qualification Standard in Kindergarten } \\
\hline Principal & Teacher \\
\hline $\begin{array}{l}\text { *Have a qualified academic undergraduate } \\
\text { diploma or four (D-IV) educational or non- } \\
\text { educational in any accredited College. } \\
\text { *Experience teaching at least 3 (three) years }\end{array}$ & $\begin{array}{l}\text { *Have a qualified academic minimum } \\
\text { education diploma or four(D-IV) or } \\
\text { Bachelor's degree (S1) in the field of early } \\
\text { in kindergarten. } \\
\text { *Minimum age is 56 years. } \\
\text { accredited program of study. }\end{array}$ \\
\hline $\begin{array}{l}\text { Specialized qualification: } \\
\text { Status as the kindergarten teacher, certified } \\
\text { educators as a kindergarten teacher and } \\
\text { certified head of kindergarten issued by } \\
\text { institutions assigned by the Government. }\end{array}$ \\
\hline
\end{tabular}

\section{Source: Regulation of the Minister of National Education, Indonesia}

Most of the issues usually happened in the operational of a kindergarten are the crisis in rules and bureaucracy in the management. Moreover, teacher reluctance to move into management positions as this may take them away from caring roles. Thus, it is the responsibility of a principal to deliver advice and guidance for every teacher fully understand the managerial roles. As an experienced in ECE environment, the main task of principal is supervising all teachers in the kindergarten for the advantages of every stakeholders. The environment of teachers working life are influenced by the administration and leadership provided by principals or preschool managers. In addition, the effectiveness of teachers and the achievement outcomes of students comes from the school leadership management (OECD, 2009; Pont, Nusche and Moorma, 2008; OECD, 2001; Phillip, 2005). 
Given the highly competitive education market, every kindergarten needs to overcome various managerial challenges in order to maintain their existence. Effective management involve qualified principal in terms of academic performance and real experiences in ECE environment.

\section{Methodology}

In this study, observations and interviews for each principal is used while collecting data. The principals are certified as teachers and principals by the Ministry of Education and Culture, Indonesia. Most of the principals had experienced in early childhood education for more than 14 years. The respondents also had degree foundations in the early childhood education program while working or before position as a teacher. Every principal competent to differentiate the roles as a teacher and principal. Even though, teacher and principal must help each other in everyday routine managerial tasks but delegating roles will produce good performance of educators and principals. The results from the observations and interviews will be analyze by content analysis method. Thus, the real experienced of principals will help to determine the managerial tasks between teacher and principal in order to enhance kindergarten overall performance better.

\section{Observation}

The observation of management meeting every Saturday with teachers facilitate the process for the following of week teaching and learning process. The collection data process involved two principals and eight teachers from two different private kindergarten centers. The observations need to determine the principal roles to plan, organize, lead and control kindergarten performance in every aspect such as curriculum, financial, physical resources or facilities and human resource development (Ganira, Paul \& Muriithi, 2016). Teachers should ready to implement the managerial task delegated in every week meeting with the principals. Participation and observation in the meeting for a month help to indicate the progress for every preparation, implementation and evaluation of the kindergarten learning activities performance. The experience principal managed to lead the kindergarten by following rule and regulation from the Ministry of Education of Indonesia. The meetings showed the cooperation among principals and teachers while delegating tasks during the weekly meeting. In this meeting, children performance reported positive result after principal guide teachers to be patient while handling children development milestone. The evaluation progress of the monthly report normally reported by the teachers in the meeting.

\section{Interviews}

The appointment for the interviews has been proposed and agreed two weeks before the interviews conducted. The principals were ready to answer and explain every question need in this research. In this interview session, two principals with more than 14 years experienced in the ECE centers. Both principals have been awarded by the MOE as the principals who had contribute to the early childhood education program in local and international event. The principals also had experienced working as teachers in an international program recommended by the MOE. The interviews focused on the real managerial roles of principals and teachers in the kindergartens. The principals managed to explain the similarities and differences of principal and teacher job scope to avoid any overlook managerial tasks during daily operational activities. Since the requirement from the kindergarten 
foundation for a principal position is 10 years as an experienced teacher, both principals showed very professional while guiding the teachers. There are three questions related such as definition of managerial roles, similarities and differences of job scope between principals and teachers, and finally the important steps managing kindergarten program. The time duration for every interview are almost two hours. Both interviews being conducted in the principals' office.

\section{Findings}

In the observation session, principal and teacher competencies from the MOE document has been taken as a reference to indicate the managerial roles between principals and teachers. The principals also provide the job scope as additional reference for a clear understanding related with the managerial task. The task should be complete before the event that will held one month from the first meeting observation. Table 3 below are the competencies required by the MOE for principals and teachers in every kindergarten.

Table 3: Principal and teacher competencies required by the Ministry of Education, Indonesia

\begin{tabular}{|l|l|}
\hline Principal Competencies & Educators Competencies \\
\hline Managerial & Pedagogy \\
\hline Personal & Personal \\
\hline Social & Social \\
\hline Supervisor & Professional \\
\hline Entrepreneur & \\
\hline
\end{tabular}

Source:

Regulation of the Minister of National Education, Indonesia

The outcomes from the two different observations is eight teachers really concern with the children needs and development. The caring roles is the basic pedagogy competencies possesses by every teacher. Activities must be suitable with the children ability as stated in the objectives of the program. The preparation, implementation and evaluation of the learning activities were planned with energetic and structure. There were a few back up plans for children who unable to complete the activity as arranged by the teachers. Each teacher managed to run the pretrial learning activities despite having problems controlling emotions of a few children. The energetic and creative teachers help to distract attentions towards fun learning. This is type of caring roles for teachers to practice which support children management.

Moreover, principal roles should be ready to see the situation before the activities began. As an experienced principal, a few planning systems being provided to help teacher conduct the activities. Every principal and teacher need to realize the different managerial roles for them to ensure the learning activity run smoothly. Table 4 explained the managing steps of learning activity blending with principal and teacher competencies. Thus, principal and teacher competencies prepared by the MOE gives impact concerning well managed of the kindergarten operations. 
INTERNATIONAL JOURNAL OF ACADEMIC RESEARCH IN BUSINESS AND SOCIAL SCIENCES Vol. 9, No. 2, Feb, 2019, E-ISSN: $2222-6990$ ๑ 2019 HRMARS

Table 4: Similarities and Differences of Managerial Roles in Sport Day Program Activity

\begin{tabular}{|c|c|c|}
\hline Steps Managing Sport Day & Principal competencies & Teacher competencies \\
\hline $\begin{array}{l}\text { Preparing proposal for the } \\
\text { learning activity (Sport } \\
\text { Day) }\end{array}$ & $\begin{array}{l}\text { Supervisor: To ensure the } \\
\text { proposal submit as } \\
\text { expected date. } \\
\text { Managerial: To ensure the } \\
\text { budget is sufficient. } \\
\text { Personal: To have a strong } \\
\text { desire to lead the } \\
\text { kindergarten and with } \\
\text { integrity. }\end{array}$ & $\begin{array}{l}\text { Pedagogy: To identify the } \\
\text { activities relevant with } \\
\text { child development } \\
\text { objectives. } \\
\text { Personal: Become the } \\
\text { children idol and } \\
\text { appreciate children even } \\
\text { diversity of beliefs, } \\
\text { religions, or cultures. }\end{array}$ \\
\hline $\begin{array}{l}\text { Identifying the curriculum } \\
\text { related with child } \\
\text { development }\end{array}$ & $\begin{array}{l}\text { Supervisor: To ensure } \\
\text { activities planned are } \\
\text { suitable with children } \\
\text { ability. }\end{array}$ & $\begin{array}{l}\text { Pedagogy: To identify } \\
\text { curriculum which support } \\
\text { children physical, moral, } \\
\text { social, cultural, emotional, } \\
\text { and intellectual progress. } \\
\text { Professional: Doing } \\
\text { observation to the } \\
\text { children in class, to } \\
\text { enhance educators' } \\
\text { professionalism }\end{array}$ \\
\hline $\begin{array}{l}\text { Utilizing the technology } \\
\text { facilities (musical } \\
\text { instruments) for children } \\
\text { needs }\end{array}$ & $\begin{array}{l}\text { Supervisor: To ensure the } \\
\text { situation is fun learning } \\
\text { and comfortable. }\end{array}$ & $\begin{array}{l}\text { Pedagogy: To identify the } \\
\text { right tools to increase } \\
\text { children self-confidence. }\end{array}$ \\
\hline $\begin{array}{l}\text { Making list the audience } \\
\text { of the program }\end{array}$ & $\begin{array}{l}\text { Social: To ensure every } \\
\text { parents and community } \\
\text { nearby will be invited. } \\
\text { Entrepreneur: Planning } \\
\text { for profit gain such as } \\
\text { rental booth to } \\
\text { community to sell foods } \\
\text { or drinks. }\end{array}$ & $\begin{array}{l}\text { Social: To make list and } \\
\text { know every important } \\
\text { audience should be } \\
\text { invited }\end{array}$ \\
\hline
\end{tabular}

\section{Conclusions}

Educational leaders such as principal and teacher should balance each competencies value to ensure things work for teaching and learning activities. The qualities of passion as an experienced educator are embodied in the kindergarten management. The integrity of institutions whether in local or international levels, is inextricably link to not only managerial roles but expert in understanding the similarities and differences positions between two positions, principal and teacher. This study offers an important insight into the experiences of principal guiding teachers by referring the competencies 
INTERNATIONAL JOURNAL OF ACADEMIC RESEARCH IN BUSINESS AND SOCIAL SCIENCES

Vol. 9, No. 2, Feb, 2019, E-ISSN: 2222-6990 C 2019 HRMARS

expected by MOE. Thus, practically this situation will help to avoid a dual identity within the workplace.

\section{Corresponding Author}

Lily Muliana Mustafa, Universiti Pendidikan Sultan Idris, Perak.

Email: mulianamustafa11@gmail.com.

\section{References}

Bridget, K. H., Ann, P., \& Christina, M. (2017). American Educational Research Association. Volume 2, Issues 4.

Daniel, M., Carol, A., Alma, H., Mary, B., (2004). Journal of Early Childhood Research, Sage Publications. Issue 2, Volume 2, Pages 157-169.

Duangjai, B. \& Saowanee, T. (2014). Procedia - Social and Behavioral Sciences, Science Direct. Volume 112, Pages 991-996.

Dunlop, A.W. (2008). A Literature Review in the Early Years. Glasgow: Learning and Teaching Scotland. Available at www.Itscotland.org.uk/images/leadershippreview_tcm4_ 499140.doc [accessed May2012]

Ebbeck, M. \& Waniganayake, M. (2003). Early Childhood Professionals: Leading today and tomorrow. Maclennan \& Petty, East Gardens, NSW.

Education at a Glance (2001). OECD Indicators. Organization for Economic Co-Operation and $\begin{array}{lll}\text { Development. } & \text { ISBN } & \text { P264192816. }\end{array}$ Education at a Glance (2009). OECD Indicators. Organization for Economic Co-Operation and Development. ISBN: 9789264024755 . Publication: 8/9/2009

Ganira, K.L., Paul, A.O., \& Muriithi, Z.W. (2016). Education Journal, Science Publishing Group. 5(5):8191

Hayden \& Jacqueline (1997). Journal of Australian Research in Early Childhood Education, Institute Education Sciences. Volume 1, Pages 49-61.

Hirokazu, Y., Christina, W., Jeanne, B., Margaret, R.B., Linda, M. E., William, T.G., Jens, L. Katherine, A.M., Deborah P., \& Martha, J.Z. (2013). Society for Research in Child Development.

http://fcd-us.org/resurces/evidence-base-preschool

Jillian, R. (2006). Leadership in Early Childhood. Allen \& Unwin Book Publishers, National Library of Australia. Third Edition.

Mat, A., Taib, Jaafar, Mohamed, S., \& Omar (2015). Procedia - Social and Behavioral Sciences, Science Direct. Volume 191, Pages 1848-1853.

Preston, D. (2013). European Early Childhood Education Research Journal. 21 (3) pp.326-338.

Philip, H. (2005). Leadership and Policy in Schools, 4:1-20. Routledge Taylor \& Francis Group.

Pont, B., Nusche, D., \& Moorman, H. (2008). Improving school leadership, Vol. 1: Policy and practice.

Paris, France: OECD Directorate for Education.

Regulation of the Minister of National Education, Indonesia. Number 1, Year 2007, 4 May 2007. Waniganayake, M. (2014). Journal of Early Childhood Education Research. Vol. 3, No.1, 2014, 65-81. World Bank (2015). Amina, D., Amer, H. \& Quentin, W. Early Childhood Education and Development in Indonesia An Assessment of Policies Using SABER. International Bank for Reconstruction and 
INTERNATIONAL JOURNAL OF ACADEMIC RESEARCH IN BUSINESS AND SOCIAL SCIENCES Vol. 9, No. 2, Feb, 2019, E-ISSN: 222 2-6990 @ 2019 HRMARS

Development. 